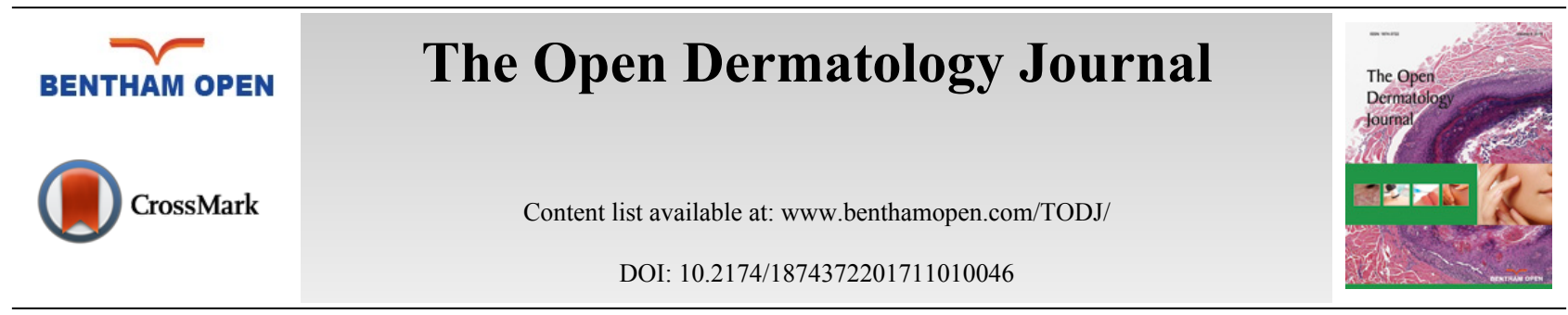

RESEARCH ARTICLE

\title{
Detection of TGF- $\beta 1$, HGF, IGF-1 and IGF-1R in Cleft Affected Mucosa of the Lip
}

Elga Sidhom ${ }^{*}$ and Mara Pilmane

Institute of Anatomy and Anthropology, Riga Stradins University, Riga, Latvia

Received: June 30, 2017

Revised: August 16, 2017

Accepted: September 12, 2017

\section{Abstract:}

Background:

Orofacial clefts are one of the most common birth defects with multifactorial and only partly understood morphopathogenesis.

\section{Objective:}

The aim of this study was to evaluate the presence of TGF- $\beta 1$, HGF, IGF-1 and IGF-1R in cleft affected mucosa of the lip.

\section{Methods:}

Lip mucosa tissue samples were obtained during surgical cleft correction from seven 2 to 6 months old children. Prepared tissue sections were stained by immunohistochemistry for TGF- $\beta 1$, HGF, IGF-1 and IGF-1R. The intensity of staining was graded semiquantitatively.

Results:

We found numerous TGF- $\beta 1$ and HGF-containing epithelial and connective tissue cells, moderate number of IGF-1 immunoreactive cells and even less pronounced presence of IGF-1R-positive cells.

\section{Conclusion:}

TGF- $\beta 1$ and HGF are present in defective epithelia and soft tissue in cleft affected lip. Expressions of IGF-1 and IGF-1R show significant differences, and both factors play a role in the morphopathogenesis of clefts.

Keywords: TGF- $\beta 1$, HGF, IGF-1, IGF-1R, Cleft, Orofacial defects, Lip mucosa.

\section{INTRODUCTION}

Orofacial clefts - cleft lips, alveolar ridges and palates are one of the most common birth defects with multifactorial and only partly understood morphopathogenesis. Over 500 different complex genetic disorders include cleft formation $[1]$.

TGF- $\beta 1$ (Transforming growth factor beta 1 ) belongs to the TGF- $\beta$ superfamily of approximately 40 cytokines and takes part in controlling proliferation, differentiation and survival in various cell types [2]. TGF- $\beta 1$ is secreted by myofibroblasts, inflammatory cells, endothelial cells and epithelial cells and takes part in burn scar contracture formation [3]. Similarly, TGF- $\beta 1$ also modulates wound inflammation and granulation tissue formation [4]. To date, the role of TGF in the formation of clefts has been evaluated in several studies. TGF- $\beta 3$ is found to be decreasingly expressed in glands and epithelium of unaffected cleft of lip, alveolus with or without cleft palate compared to healthy

* Address correspondence to this author at the Institute of Anatomy and Anthropology, Riga Stradins University, Kronvalda blvd. 9, Riga, LV-1010, Latvia; Tel: +371 29336041; Fax: +371 67320862; E-mail: Elga.Sidhoma@rsu.lv 
tissue [5]. Simultaneously, TGF-alpha has been studied in nonsyndromic clefts and healthy control tissue samples; it has been shown to have low protein expression in glands of cleft of the lip or palate tissue, as well as unaffected control tissue obtained from the lip and alveolus [6].

HGF (Hepatocyte growth factor) is secreted by tumor stromal cells; and cancer-associated fibroblasts promote growth, survival and migration of cancer cells in an HGF-dependent manner [7]. HGF is thought to be responsible for cancer cell migration, as well as their invasion via cytoskeletal assembly, reorganization and dynamics. HGF contributes to cytoskeleton remodeling, interactions and distribution [8].

IGF-1 (Insulin like growth factor 1) is phylogenetically ancient neurotrophic hormone with essential role in central nervous system development and maturation. It is especially important in cellular neuroplasticity and signals through its glycoprotein receptor IGF-1R (Insulin like growth factor 1 receptor) [9]. IGF-1 regulates survival and differentiation of many types of cells, including stem cells and placental cells, and stimulates prenatal and postnatal growth. In prenatal life, the synthesis of IGF-1 itself is regulated by various paracrine and endocrine factors and is synthesized as required. IGF-1R is a transmembrane tetramer receptor and its downregulation is associated with the inhibition of differentiation and induction of apoptosis [10]. IGF-1 and IGF-1R also play an initial role in cancerogenesis and their activity leads to increased mitogenesis, cell cycle progression and protection against apoptosis [11].

The aim of this study was to evaluate the presence of TGF- $\beta 1$, HGF, IGF-1 and IGF-1R in cleft affected mucosa of the lip.

\section{MATERIALS AND METHODS}

Lip mucosa tissue samples were obtained during surgical lip correction from seven 2 to 6 months old children (five boys and two girls) in the Cleft Lip and Palate Centre at the Institute of Stomatology of Riga Stradins University. Six were patients with unilateral cleft lip and palate and one patient was with bilateral cleft lip and palate.

The study was performed in accordance with the 1964 Declaration of Helsinki. All tissue samples were obtained after receiving written informed consent from the parents of the patients. The study was approved by the Ethical Committee at Riga Stradins University, permit issued in 2003.

Lip mucosa tissue was fixed in Stefanini's solution [12]. Stefanini's solution was made of $20 \mathrm{~g}$ paraformaldehyde, $150 \mathrm{ml}$ picric acid, $425 \mathrm{ml}$ Sorensen's phosphate buffer ( $\mathrm{pH} 7.2)$ and $425 \mathrm{ml}$ distilled water, and stored in fridge. Further tissue samples were dehydrated and embedded in paraffin. Four micrometers thick sections were prepared and further stained routinely with hematoxylin and eosin [13].

TGF- $\beta 1$ (code orb7087, obtained from rabbit, dilution 1:100, Biorbyt Limited, Cambridge, UK), HGF (catalog number AF-294-NA, Lot number ALP01, obtained from goat, dilution 1:300, R\&D Systems, USA), IGF-1 (catalog number MAB291, Lot number 56408, obtained from mouse, dilution 1:50, R\&D Systems, USA) and IGF-1R (catalog number AF-305-NA, Lot number VL03, obtained from goat, dilution 1:100, R\&D Systems, USA) primary antibodies were used by biotin - streptavidin immunohistochemistry (IMH) [14].

Lip mucosa tissue samples were deparaffinized and washed in alcohol and water, then washed for 10 minutes in wash buffer (Tris-buffered saline) and placed for 5 minutes in EDTA boiling buffer in microwave; then cooled down and washed twice for 5 minutes in wash buffer. To decrease background staining, we used normal blocking serum for 20 minutes. All tissue samples were incubated with primary antibodies for 1 hour. Further, washing for 10 minutes in wash buffer and incubation for 30 minutes with LSAB+LINK with biotin related secondary antibodies (code K1015, DakoCytomation, Denmark) was performed. Afterwards we performed another washing for 5 minutes in wash buffer. Lip mucosa samples were incubated for 25 minutes with LSAB+LINK with enzyme peroxidase labeled streptavidine (code K0690, DakoCytomation, Denmark), which was followed by 5 minutes washing in wash buffer and 10 minutes processing with liquid DAB substrate-chromogen system (code K3468, DakoCytomation, Denmark) to obtain positive structure staining in brown color. Samples were then rinsed in running water and counterstained with hematoxylin to stain the nuclei blue.

All antibodies used in the study were tested for positive and negative control.

Image processing and analysis was performed using Image Pro Plus 6.0 software (Media Cybernetics, Silver Spring, Maryland, USA).

The intensity of immunostaining was graded semiquantitatively and labeled as follows: no positive structures in the 
visual field were labeled as 0 , few positive structures in the visual field were labeled with + , moderate number of positive structures in the visual field were labeled with ++ , numerous positive structures in the visual field were labeled with +++ , abundance of positive structures in the visual field was marked with $++++[15]$.

\section{RESULTS}

Mostly numerous (+++) TGF- $\beta 1$-containing structures were detected in all lip tissue samples (Fig. 1). TGF- $\beta 1$ is found to be expressed in epitheliocytes, as well as fibroblasts and macrophages in subepithelial tissue. In one patient's tissue sample, we observed factor positive salivary glands, while another tissue sample showed patchy immunoreactivity. Occasional endothelial cells of the capillary walls were also immunopositive for TGF- $\beta 1$.

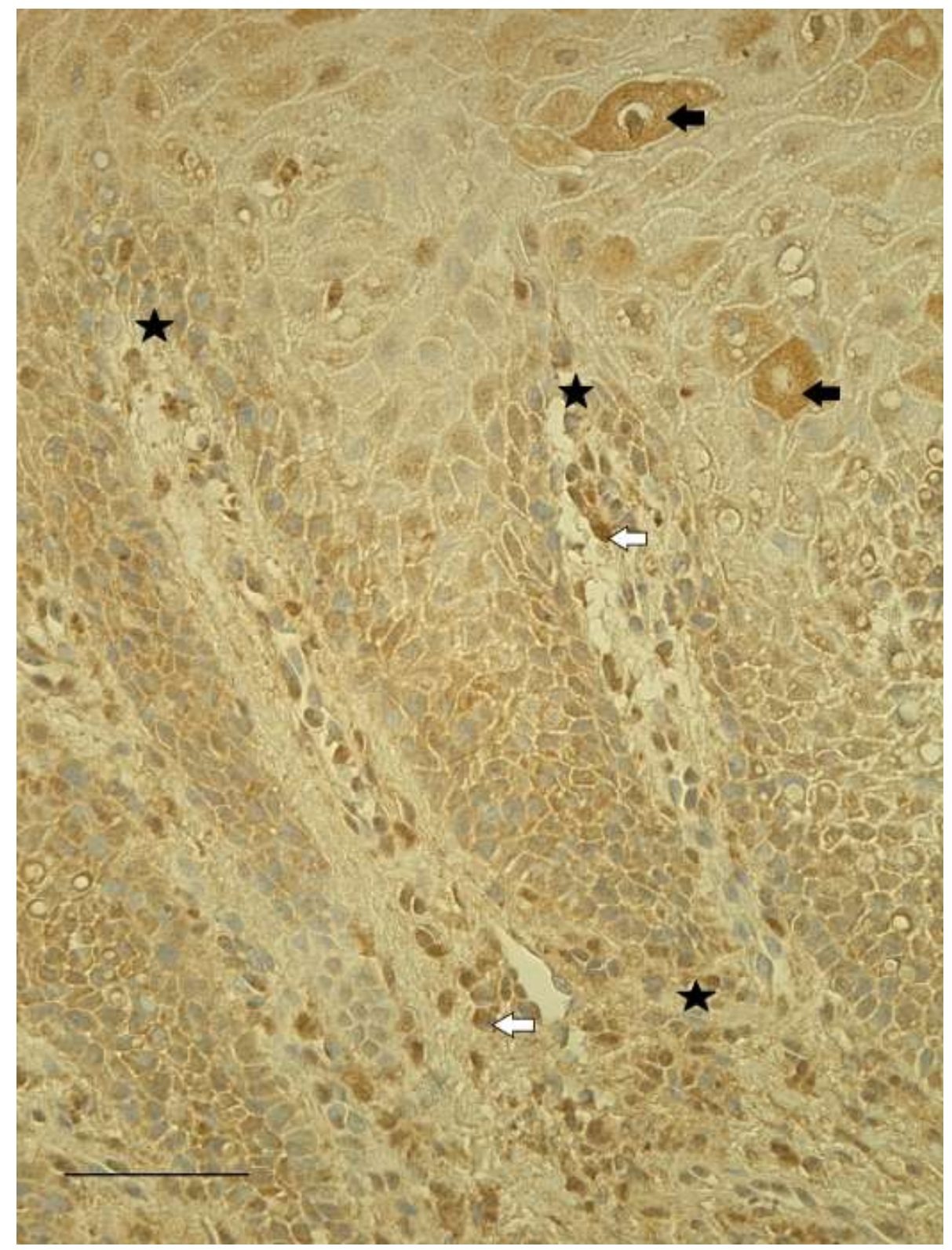

Fig. (1). Numerous TGF- $\beta 1$-positive fibroblasts and macrophages in subepithelial tissue (white arrows), as well as TGF- $\beta 1$ containing epithelial cells (black arrows). Occasional endothelial cells of the capillary walls are immunopositive for TGF- $\beta 1$. Epithelium-connective tissue junction is marked with stars. TGF- $\beta 1 \mathrm{IMH}, \mathrm{x} 250$, scale bar: $4.1 \mu \mathrm{m}$.

HGF-positive epitheliocytes, macrophages, as well as fibroblasts were found in all patients' tissue samples. In epithelia, we detected mostly numerous (+++) HGF-positive cells, meanwhile HGF-positive fibroblasts and macrophages observed in subepithelial tissue varied from few $(+)$ to abundance $(++++)$ in the visual field (Fig. 2). 


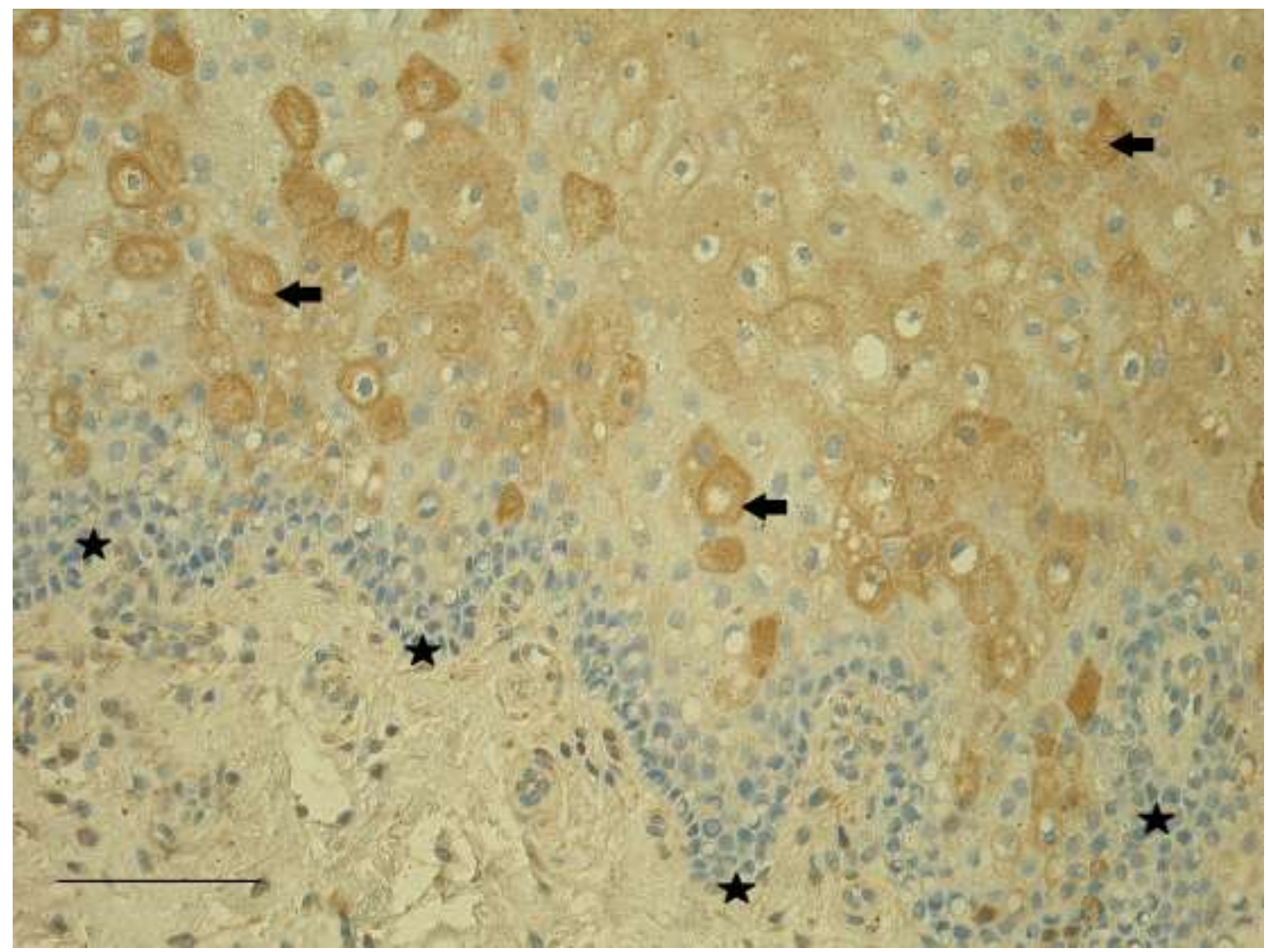

Fig. (2). Numerous HGF-positive epithelial cells (black arrows) in cleft affected lip mucosa. Epithelium-connective tissue junction is marked with stars. HGF IMH, x200, scale bar: $7.25 \mu \mathrm{m}$.

Mostly moderate $(++)$ number of IGF-1-containing epithelial cells and connective tissue cells (fibroblasts, macrophages) (Fig. 3), as well as IGF-1R-containing epithelial cells were found in most of our lip mucosa tissue samples. The expression of both factors was often with patchy distribution and the immunoreactive cells were observed in scattered regions. Simultaneously the immunoreactivity of IGF-1R in subepithelial tissue was weak and only some of the tissue samples contained few IGF-1R-positive fibroblasts and macrophages.

\section{DISCUSSION}

Orofacial clefts are constituted of cleft lip, cleft palate, and cleft lip and palate. Clefts are the largest group of craniofacial malformations. As there is strong familial association, major etiology factor is the genetic component. While cleft palate or cleft clip and palate require surgical correction due to difficulty in breastfeeding, untreated cleft lip or cleft lip and palate leads to social discrimination [16]. Orofacial clefting is associated with delayed facial growth or fusion. Various signaling pathways have been suggested as the culprit for the development of the facial malformations while one detailed mechanism is not known yet [17]. In the current study, we evaluated lip mucosa tissue samples obtained from seven children with cleft lip and palate.

TGF- $\beta 1$ contributes to the formation of collagenous connective tissue and is expressed by large amount of fibroblasts and chronic inflammatory cells in reactive gingival overgrowths [18]. Compared with typical wounds there is a higher ratio of TGF- $\beta 1$ in fetal wounds. Fetal wounds are known to heal rapidly and without scar formation early in gestation [19]. Various studies using animal models have looked at the role of TGF in the formation of clefts. It has been found that the loss of TGF- $\beta$ signaling in the palatal epithelium leads to soft palate muscle cell proliferation and differentiation defects [20]. We found numerous TGF- $\beta 1$-containing epithelial cells, fibroblasts and macrophages. Some of the endothelial cells in capillaries of our tissue samples were also immunopositive for TGF- $\beta 1$ and in certain conditions endothelial cells can contain growth factors. We suggest that TGF- $\beta 1$ takes part in the formation of both defective epithelia and soft tissue in cleft affected lip. 
Our tissue samples showed prominent immunoreactivity also for HGF with overall numerous HGF-positive epithelial and subepithelial cells. HGF is associated with head and neck squamous cell carcinoma and contributes to proliferation, metastasis, angiogenesis, the tumor microenvironment and the immune system [21]. Apart from tumorogenesis, it has been shown that HGF is responsible for the development of stria vascularis and nonsensory structures of the cochlea. Lack of HGF signaling in the inner ear leads to hearing loss [22]. HGF is a mitogen and motility factor and primarily regulates epithelial cell function. HGF actively augments the proliferation of corneal epithelial cells in normal and inflammatory conditions [23]. Thus, HGF also takes part in the development of the defective epithelia and soft tissue in cleft affected lip mucosa.

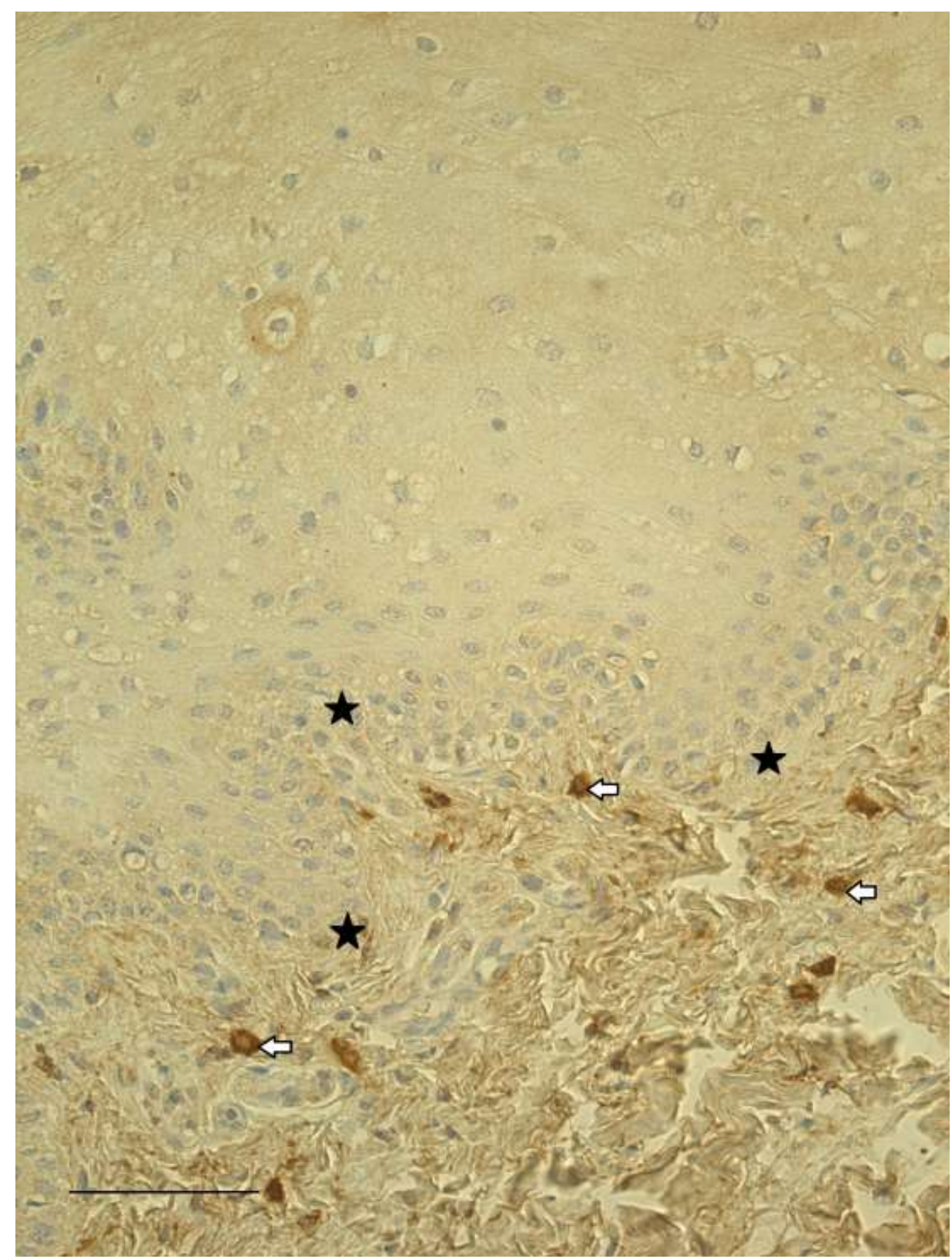

Fig. (3). IGF-1-immunoreactive cells (white arrows) in subepithelial tissue of cleft affected lip tissue. Epithelium-connective tissue junction is marked with stars. IGF-1 IMH, x250, scale bar: $4.1 \mu \mathrm{m}$.

IGF-1 is known to take part in the postnatal facial development as it regulates vertical face growth [24]. IGF-1 also stimulates proliferation, wound healing and differentiation processes of periodontal ligament cells under inflammatory conditions [25]. Furthermore, IGF-1 and IGF-1R are expressed early during embryogenesis and have shown antagonizing effects. Overexpression of IGF-1 leads to anterior expansion of head neural tissue and ectopic eyes, while IGF-1R depletion greatly reduces head structures [26]. We found moderate number of IGF-1-containing epithelial cells 
and connective tissue cells, as well as IGF-1R-containing epithelial cells. Simultaneously only few IGF-1R-positive connective tissue cells were found in some of the studied tissue samples. Therefore, we suggest that expressions of IGF-1 and IGF-1R show significant differences, and both factors play a role in the morphopathogenesis of clefts.

\section{CONCLUSION}

TGF- $\beta 1$ and HGF are present in defective epithelia and soft tissue in cleft affected lip. Expressions of IGF-1 and IGF-1R show significant differences, and both factors play a role in the morphopathogenesis of clefts.

\section{ETHICS APPROVAL AND CONSENT TO PARTICIPATE}

Not applicable.

\section{HUMAN AND ANIMAL RIGHTS}

No Animals/Humans were used for studies that are base of this research.

\section{CONSENT FOR PUBLICATION}

Not applicable.

\section{CONFLICT OF INTEREST}

The authors declare no conflict of interest, financial or otherwise.

\section{ACKNOWLEDGEMENTS}

Riga Stradins University project "Longitudinal research on cleft morphopathogenesis".

\section{REFERENCES}

[1] Wójcicki P, Koźlik MJ, Wójcicka K. Genetic factors in selected complex congenital malformations with cleft defect. Adv Clin Exp Med 2016; 25(5): 977-87.

[http://dx.doi.org/10.17219/acem/61911] [PMID: 28028964]

[2] Rider CC, Mulloy B. Heparin, Heparan sulphate and the TGF- $\beta$ Cytokine superfamily. Molecules 2017; $22(5)$ : E713. [http://dx.doi.org/10.3390/molecules22050713] [PMID: 28468283]

[3] Tan J, Wu J. Current progress in understanding the molecular pathogenesis of burn scar contracture. Burns Trauma 2017; 5: 14. [http://dx.doi.org/10.1186/s41038-017-0080-1] [PMID: 28546987]

[4] Koivisto L, Heino J, Häkkinen L, Larjava H. Integrins in wound healing. Adv Wound Care (New Rochelle) $2014 ; 3(12)$ : $762-83$. [http://dx.doi.org/10.1089/wound.2013.0436] [PMID: 25493210]

[5] Rullo R, Gombos F, Ferraraccio F, et al. TGFbeta3 expression in non-syndromic orofacial clefts. Int J Pediatr Otorhinolaryngol 2006; 70(10): 1759-64.

[http://dx.doi.org/10.1016/j.ijporl.2006.05.019] [PMID: 16837067]

[6] Rullo R, Gombos F, Ferraraccio F, et al. TGF alpha has low protein expression in nonsyndromic clefts. J Craniofac Surg 2007; 18(6): 1276-80. [http://dx.doi.org/10.1097/scs.0b013e3180de6506] [PMID: 17993868]

[7] Owusu BY, Galemmo R, Janetka J, Klampfer L. Hepatocyte growth factor: A key tumor-promoting factor in the tumor microenvironment. Cancers (Basel) 2017; 9(4): E35. [http://dx.doi.org/10.3390/cancers9040035] [PMID: 28420162]

[8] Xiang C, Chen J, Fu P. HGF/Met Signaling in Cancer Invasion: The impact on cytoskeleton remodeling. Cancers (Basel) 2017 ; 9(5): E44. [http://dx.doi.org/10.3390/cancers9050044] [PMID: 28475121]

[9] Dyer AH, Vahdatpour C, Sanfeliu A, Tropea D. The role of Insulin-Like growth factor 1 (IGF-1) in brain development, maturation and neuroplasticity. Neuroscience 2016; 325: 89-99.

[http://dx.doi.org/10.1016/j.neuroscience.2016.03.056] [PMID: 27038749]

[10] Youssef A, Aboalola D, Han VK. The roles of Insulin-Like growth factors in mesenchymal stem cell niche. Stem Cells Int 2017. [http://dx.doi.org/10.1155/2017/9453108]

[11] Kasprzak A, Kwasniewski W, Adamek A, Gozdzicka-Jozefiak A. Insulin-like growth factor (IGF) axis in cancerogenesis. Mutat Res Rev Mutat Res 2017; 772: 78-104.

[http://dx.doi.org/10.1016/j.mrrev.2016.08.007] [PMID: 28528692]

[12] Stefanini M, De Martino C, Zamboni L. Fixation of ejaculated spermatozoa for electron microscopy. Nature 1967; 216(5111): 173-4. [http://dx.doi.org/10.1038/216173a0] [PMID: 4862079] 
[13] Fischer AH, Jacobson KA, Rose J, Zeller R. Hematoxylin and eosin staining of tissue and cell sections. CSH Protoc 2008. [http://dx.doi.org/10.1101/pdb.prot4986]

[14] Hsu SM, Raine L, Fanger H. The use of antiavidin antibody and avidin-biotin-peroxidase complex in immunoperoxidase technics. Am J Clin Pathol 1981; 75(6): 816-21.

[http://dx.doi.org/10.1093/ajcp/75.6.816] [PMID: 6167159]

[15] Pilmane M, Luts A, Sundler F. Changes in neuroendocrine elements in bronchial mucosa in chronic lung disease in adults. Thorax 1995; 50(5): 551-4. [http://dx.doi.org/10.1136/thx.50.5.551] [PMID: 7541167]

[16] Beaty TH, Marazita ML, Leslie EJ. Genetic factors influencing risk to orofacial clefts: today's challenges and tomorrow's opportunities. F1000 Res 2016; 5: 2800.

[http://dx.doi.org/10.12688/f1000research.9503.1] [PMID: 27990279]

[17] Kurosaka H. The roles of hedgehog signaling in upper lip formation. Biomed Res Int 2015; 6. [http://dx.doi.org/10.1155/2015/901041]

[18] Epivatianos A, Andreadis D, Iordanidis S. Myofibroblasts and transforming growth factor-beta1 in reactive gingival overgrowths. J Oral Maxillofac Res 2013; 4(1): e3.

[http://dx.doi.org/10.5037/jomr.2013.4103] [PMID: 24422026]

[19] Namazi MR, Fallahzadeh MK, Schwartz RA. Strategies for prevention of scars: what can we learn from fetal skin? Int J Dermatol 2011; 50(1): 85-93. [http://dx.doi.org/10.1111/j.1365-4632.2010.04678.x] [PMID: 21039435]

[20] Iwata J, Suzuki A, Yokota T, et al. TGF $\beta$ regulates epithelial-mesenchymal interactions through WNT signaling activity to control muscle development in the soft palate. Development 2014; 141(4): 909-17. [http://dx.doi.org/10.1242/dev.103093] [PMID: 24496627]

[21] Hartmann S, Bhola NE, Grandis JR. HGF/Met signaling in head and neck cancer: impact on the tumor microenvironment. Clin Cancer Res 2016; 22(16): 4005-13.

[http://dx.doi.org/10.1158/1078-0432.CCR-16-0951] [PMID: 27370607]

[22] Shibata S, Miwa T, Wu HH, Levitt P, Ohyama T. Hepatocyte growth factor-c-MET signaling mediates the development of nonsensory structures of the mammalian cochlea and hearing. J Neurosci 2016; 36(31): 8200-9. [http://dx.doi.org/10.1523/JNEUROSCI.4410-15.2016] [PMID: 27488639]

[23] Omoto M, Suri K, Amouzegar A, et al. Hepatocyte growth factor suppresses inflammation and promotes epithelium repair in corneal injury. Mol Ther 2017.

[http://dx.doi.org/10.1016/j.ymthe.2017.04.020]

[24] Masoud MI, Marghalani HY, Alamoudi NM, El Derw D, Masoud IM, Gowharji NF. Longitudinal relationship between insulin-like growth factor-1 levels and vertical facial growth. J Orofac Orthop 2015; 76(5): 440-50. [http://dx.doi.org/10.1007/s00056-015-0305-5] [PMID: 26272169]

[25] Reckenbeil J, Kraus D, Stark H, et al. Insulin-like growth factor 1 (IGF1) affects proliferation and differentiation and wound healing processes in an inflammatory environment with p38 controlling early osteoblast differentiation in periodontal ligament cells. Arch Oral Biol 2017; 73: 142-50.

[http://dx.doi.org/10.1016/j.archoralbio.2016.10.010] [PMID: 27769028]

[26] Richard-Parpaillon L, Héligon C, Chesnel F, Boujard D, Philpott A. The IGF pathway regulates head formation by inhibiting Wnt signaling in Xenopus. Dev Biol 2002; 244(2): 407-17.

[http://dx.doi.org/10.1006/dbio.2002.0605] [PMID: 11944947]

\section{(C) 2017 Sidhom and Pilmane.}

This is an open access article distributed under the terms of the Creative Commons Attribution 4.0 International Public License (CC-BY 4.0), a copy of which is available at: (https://creativecommons.org/licenses/by/4.0/legalcode). This license permits unrestricted use, distribution, and reproduction in any medium, provided the original author and source are credited. 